\title{
KARAKTERISASI METIL SELULOSA YANG DISINTESIS DARI KULIT JAGUNG (Zea mays)
}

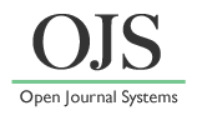

\author{
Lena Rahmidar ${ }^{*}$, Intan Nurilah ${ }^{2}$, Tety Sudiarty ${ }^{2}$ \\ ${ }^{1}$ Universitas BSI Bandung, Jawa Barat \\ ${ }^{2}$ UIN Sunan Gunung Djati Bandung, Jawa Barat \\ *Email: lena@bsi.ac.id
}

\begin{abstract}
ABSTRAK
Kulit jagung memiliki kandungan selulosa cukup banyak yaitu sekitar $42 \%$, yang belum dimanfaatkan secara maksimal. Penelitian ini bertujuan untuk membuat metil selulosa dari selulosa limbah kulit jagung. Metil selulosa merupakan salah satu turunan selulosa yang banyak dimanfaatkan di industri makanan, kosmetik, farmasi dan lain-lain. Sintesis metil selulosa ini melalui beberapa tahap yaitu isolasi selulosa, metilasi (sintesis metil selulosa), karakterisasi, uji titik leleh dan uji kelarutan. Sintesis metil selulosa dilakukan dengan dua variasi pelarut yaitu metil selulosa-air dan metil selulosa-aseton. Berdasarkan analisis FTIR metil selulosa yang dihasilkan, maka diketahui puncak khas metil selulosa yaitu 3444,87 untuk O-H, 2899,01 untuk C-H pada metil selulosa-air dan 3429,43 untuk O-H, 2926,01 untuk C-H pada metil selulosa-aseton. Dari hasil uji kelarutan juga diketahui bahwa metil selulosa-air dan metil selulosaaseton larut dalam $\mathrm{NaOH}$. Hal ini menunjukkan bahwa kedua metil selulosa yang dihasilkan memiliki derajat substitusi sekitar 0,4-0,6.
\end{abstract}

Kata kunci: Kulit jagung; selulosa; metil selulosa; derajat substitusi; limbah pertanian.

\section{PENDAHULUAN}

Jagung merupakan salah satu sumber karbohidrat yang dikonsumsi masyarakat Indonesia. Produksi jagung di Indonesia cukup besar bahkan mengalami peningkatan setiap tahunnya. Menurut data Badan Pusat Statistik (BPS), produksi jagung di Indonesia pada tahun 2015 sebesar 19,61 juta ton. Produksi jagung yang cukup besar ini menimbulkan dampak pada jumlah limbah pertanian, dalam hal ini limbah jagung yang dihasilkan. Dari hasil panen buah jagung, bobot limbah kulit jagung berkisar antara $38,38 \%$ (Sumarwan, 2016).

Selama ini, kulit jagung yang ada belum dimanfaatkan secara maksimal. Kulit jagung hanya dimanfaatkan sebagai pakan ternak, pembungkus makanan tradisional, dan kerajinan tradisional. Untuk memaksimalkan potensi kulit jagung, maka diperlukan penelitian lebih lanjut. Salah satu penelitian yang sedang dikembangkan yaitu memanfaatkan selulosa dari kulit jagung. Seperti yang diketahui bahwa komposisi kimia terbesar dalam kulit jagung adalah selulosa yaitu sekitar 42\% (Ginting, 2016).

Pada penelitian sebelumnya, selulosa dari kulit jagung ini dimanfaatkan sebagai plastik biodegradable. Plastik biodegradable atau bioplastik merupakan salah satu inovasi yang diciptakan untuk mengurangi sampah plastik. Plastik ramah lingkungan ini terbuat dari campuran polimer sintetis dengan bahan alami seperti pati atau selulosa (Dirgantara, 2013). Selain itu, turunan selulosa seperti metil selulosa pun banyak dimanfaatkan.

Metil selulosa adalah salah satu eter selulosa komersial yang paling penting dan telah digunakan di banyak aplikasi industri. Salah satu aplikasi metil selulosa yaitu dalam bidang pangan. Metil selulosa sering digunakan sebagai emulsifier atau pengemulsi untuk mencegah pemisahan dua cairan campuran yang berbeda kepolarannya. Metil selulosa yang digunakan sebagai emulsifier ini biasanya adalah metil selulosa yang memiliki nilai derajat substitusi sekitar 1,3-2,5. Karena metil selulosa yang memiliki nilai derajat substitusi disekitar 1,3-2,5 larut dalam air (Rimdusit, 2008). Derajat substitusi didefinisikan sebagai jumlah rata-rata substituen per unit anhidro glukosa. Untuk meningkatkan nilai derajat substitusi (DS) ini biasanya ditambahkan pelarut seperti aseton atau toluen pada saat proses metilasi (Nasatto, 2015). 
Tujuan penelitian ini adalah untuk menyintesis metil selulosa dari limbah kulit jagung, serta karakterisasi hasil sintesisnya menggunakan beberapa metode, diantaranya spektroskopi FTIR untuk mengetahui derajat substitusi yang terjadi sebagai indikator seberapa banyak gugus metil yang berhasil dimasukkan ke dalam selulosa tersebut, karena derajat metilasi ini akan menentukan sifat kepolaran metil selulosa yang dihasilkan.

\section{METODE PENELITIAN}

Alat dan Bahan

Alat-alat yang digunakan meliputi labu ukur $250 \mathrm{~mL}$, labu ukur $100 \mathrm{~mL}$, corong Buchner, alat refluks, pemanas, oven, blender, neraca analitik, kaca arloji, spatula, batang pengaduk, pipet volume $20 \mathrm{~mL}$, pipet tetes, gelas ukur $100 \mathrm{~mL}$. Untuk pengujian gugus fungsi selulosa, dan metil selulosa digunakan instrumen FTIR.

Bahan-bahan yang digunakan dalam penelitian ini adalah $\mathrm{NaOH}$ p.a $(50 \%), \mathrm{NaOH}$ teknis $4 \%, \mathrm{NaOH}$ teknis $(0.675 \mathrm{M}), \mathrm{CH}_{2} \mathrm{Cl}_{2}$ p.a, $\left(\mathrm{CH}_{3}\right)_{2} \mathrm{CO}$ p.a, $\mathrm{CH}_{3} \mathrm{COOH}(10 \%), \mathrm{CH}_{3} \mathrm{COOH}$ glasial, $\mathrm{NaClO}_{2}$ p.a $(0.1878 \mathrm{M})$ dan air suling atau aquades.

\section{Preparasi sampel kulit jagung}

Sampel yang digunakan dalam penelitian ini adalah kulit jagung. Kulit jagung yang digunakan berasal dari pasar gede bage Bandung. Kulit jagung yang diperoleh dari pasar tersebut dicuci terlebih dahulu untuk menghilangkan kotoran. Setelah itu dikeringkan diudara terbuka hingga setengah kering, baru dikalsinasi pada suhu $50^{\circ} \mathrm{C}$ selama 24 jam. Kulit jagung yang telah kering kemudian dihaluskan dan disaring dengan saringan 80 mesh. Setelah disaring, didapatlah serbuk kulit jagung. Serbuk kulit jagung ini akan diproses pada tahap berikutnya.

\section{Isolasi selulosa kulit jagung}

Isolasi selulosa kulit jagung ini terdiri dari dua tahap. Tahap pertama adalah perlakuan dengan alkali. $25 \mathrm{~g}$ serbuk kulit jagung ditambah $250 \mathrm{~mL}$ larutan $\mathrm{NaOH} 4 \%$, dipanaskan di penangas air pada suhu $(80-90)^{\circ} \mathrm{C}$ selama 4 jam. Setelah itu, disaring dan residunya dicuci dengan akuades berlebih. Tahap kedua adalah bleaching. Bleaching ini menggunakan larutan $\mathrm{NaClO}_{2}$ (0.1878 M), $\mathrm{NaOH}$ dan $\mathrm{CH}_{3} \mathrm{COOH}$ glasial.
Residu yang telah dicuci dengan akuades berlebih kemudian ditambah larutan $\mathrm{NaOH}$, $\mathrm{CH}_{3} \mathrm{COOH}$ glasial, $\mathrm{NaClO}_{2}$, dipanaskan dipenangas air pada suhu $(80-90)^{\circ} \mathrm{C}$ selama 4 jam. Setelah itu, disaring dan residunya dicuci dengan akuades berlebih. Kemudian dikalsinasi pada suhu $50^{\circ} \mathrm{C}$ selama $10 \mathrm{jam}$.

\section{Sintesis metil selulosa}

Setelah diperoleh selulosa dari kulit jagung, langkah selanjutnya yaitu sintesis metil selulosa dari selulosa kulit jagung. Pada sintesis metil selulosa ini dilakukan dua variasi. Tujuannya adalah untuk mengoptimalkan nilai DS dari metil selulosa tersebut.

Sebanyak $5 \mathrm{~g}$ selulosa dilarutkan dalam $50 \% \mathrm{NaOH}$ dan stirrer selama 24 jam. Campuran tesebut kemudian ditambahkan akuades $100 \mathrm{~mL}$ (untuk variasi satu) dan $\left(\mathrm{CH}_{3}\right)_{2} \mathrm{CO}$ (untuk variasi dua). Setelah itu campuran direfluks pada suhu $(60-70)^{\circ} \mathrm{C}$ dan di stirrer selama 6 jam. Dilakukan penambahan $\mathrm{CH}_{2} \mathrm{Cl}_{2}$ sebagai agen metilasinya. Setelah itu, dinetralkan dengan $\mathrm{CH}_{3} \mathrm{COOH}$ 10-50\%. Campuran kemudaian disaring, dicuci dengan akuades panas (suhu $80^{\circ} \mathrm{C}$ ) dan disaring kembali. Residu hasil penyaringan kemudian dikalsinasi pada suhu $50^{\circ} \mathrm{C}$ selama 6 jam.

\section{Karakterisasi selulosa dan metil selulosa}

Produk sintesis selulosa dan metil selulosa dari kulit jagung dikarakterisasi dengan FTIR. Sampel (selulosa dan metil selulosa) yang digunakan dalam bentuk serbuk. Sampel yang siap diukur ditempatkan pada tempat sampel dari alat interferometer, kemudian ditunggu spektra yang diperoleh pada layar komputer sehingga diperoleh data anaisis FTIR.

\section{Uji kelarutan dan uji titik leleh}

Uji kelarutan dilakukan dengan melarutkan metil selulosa didalam beberapa larutan, seperti larutan $\mathrm{NaOH} 4 \%$, larutan $\mathrm{CH}_{3} \mathrm{COOH}$ glasial, dan aquades $\left(\mathrm{T}=(5-15)^{\circ} \mathrm{C}\right)$.

Uji titik leleh dilakukan dengan cara memasukkan sampel serbuk metil selulosa kedalam pipa kapiler. Kemudian pipa kapiler tersebut diletakan pada kalorimeter. Pada kalorimeter tersebut juga dipasang terometer untuk mengetahui titik leleh selulosa. 
Kalorimeter tersebut kemudian dipanaskan hingga metil selulosa meleleh.

\section{HASIL DAN PEMBAHASAN}

Isolasi selulosa kulit jagung

Pada penelitian ini, isolasi selulosa dilakukan dua tahap, yaitu perlakuan dengan alkali, dan pemutihan (bleaching). Perlakuan dengan alkali ini bertujuan untuk melarutkan bahan selain selulosa yang ada pada kulit jagung seperti lignin, asam organik sehingga selulosa terpisah dari lignin dan komponen lainnya. Lignin merupakan polimer tiga dimensi yang terdiri dari unit fenil propana melalui ikatan eter (C-O-C) dan ikatan karbon (C-C). Bila lignin berdifusi dengan larutan alkali maka akan terjadi pelepasan gugus metoksil yang membuat lignin larut dalam alkali. Setelah itu, lignin dan komponen lainnya dipisahkan dengan pencucian dan penyaringan. Reaksi pemutusan ikatan antara lignin dan selulosa mengunakan $\mathrm{NaOH}$ dapat dilihat pada Gambar 1.

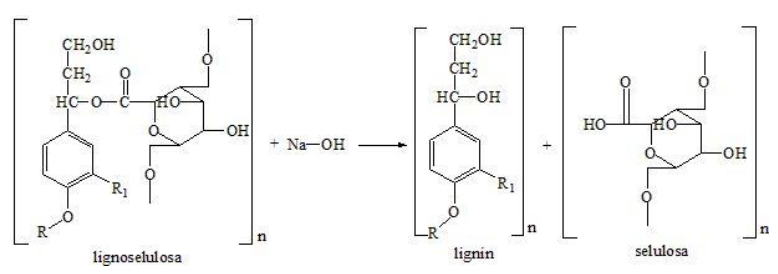

Gambar 1. Reaksi pada proses delignifikasi

Proses pemutihan (bleaching) dilakukan dengan menggunakan larutan $\mathrm{NaOH}, \mathrm{CH}_{3} \mathrm{COOH}$ glasial, dan $\mathrm{NaClO}_{2}$. Seperti pada treatment alkali, penambahan larutan $\mathrm{NaOH}$ ini bertujuan untuk menghilangkan lignin yang masih tersisa. Sedangkan larutan $\mathrm{CH}_{3} \mathrm{COOH}$ glasial berperan dalam proses dehemiselulosa yaitu melepaskan hemiselulosa dari struktur selulosa (Pinotti, 2007).

Rantai hemiselulosa lebih pendek dibandingkan rantai selulosa, karena derajat polimerisasinya yang lebih rendah. Berbeda dengan selulosa, polimer hemiselulosa berbentuk tidak lurus tetapi merupakan polimer-polimer bercabang dan strukturnya tidak berbentuk kristal. Hal ini yang menjadikan hemiselulosa lebih mudah dimasuki pelarut dan bereaksi dengan larutan dibanding selulosa (Rachmawati, 2013).
Selain berperan dalam proses dehemiselulosa (penghilangan hemiselulosa), larutan $\mathrm{CH}_{3} \mathrm{COOH}$ glasial juga berperan dalam pemutihan menggunakan $\mathrm{NaClO}_{2}$. Karena pemutihan menggunakan $\mathrm{NaClO}_{2}$ akan berlangsung dengan sempurna dalam suasana asam. Proses terakhir adalah penambahan larutan $\mathrm{NaClO}_{2}$, yang akan mengoksidasi struktur lignin sehingga larut dalam air. Berikut ini reaksi pemutihan menggunakan natrium klorit:

$5 \mathrm{ClO}_{2}^{-}+4 \mathrm{H}^{+} \rightarrow 4 \mathrm{ClO}_{2}+\mathrm{Cl}^{-}+2 \mathrm{H}_{2} \mathrm{O}$

$4 \mathrm{ClO}_{2}^{-}+2 \mathrm{H}^{+} \rightarrow 2 \mathrm{ClO}_{2}+\mathrm{Cl}^{-}+\mathrm{ClO}_{3}^{-}+\mathrm{H}_{2} \mathrm{O}$

Pada tahap isolasi ini dihasilkan selulosa berupa padatan berwarna putih. Selulosa hasil seintesis dapat dilihat pada Gambar 2.

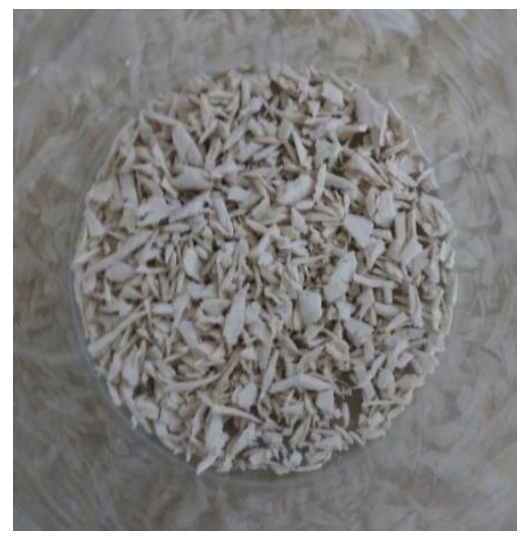

Gambar 1. Selulosa dari kulit jagung

\section{Sintesis metil selulosa kulit jagung}

Sintesis metil selulosa pada penelitian ini meliputi tahapan alkalisasi dan metilasi. Tahap pertama adalah alkalisasi karena selulosa tidak larut dalam air dan pelarut organik yang paling umum, media alkali $(\mathrm{NaOH})$ digunakan untuk membuat serat selulosa menggembung dan mendapatkan selulosa alkali. Ketika molekul selulosa menggembung, maka akan memudahkan proses metilasi sehingga dihasilkan metil selulosa. Proses alkalisasi dapat dilihat pada Gambar 3. 


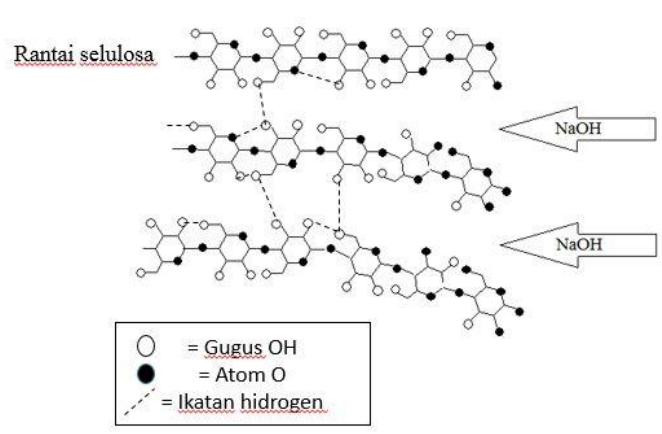

Gambar 3. Alkalisasi selulosa

Selulosa alkali yang telah terbentuk pada tahap alkalisasi akan bereaksi dengan zat eterifikasi. Zat eterifikasi (agen metilasi) yang digunakan adalah metilen klorida. Gugus metil dari metilen klorida akan menggantikan gugus hidroksil pada selulosa. Gugus hidroksil yang digantikan pada selulosa yaitu pada $\mathrm{C} 2, \mathrm{C} 3$, atau C6. Setelah penambahan zat eterfikasi, campuran ditambahkan pula air (variasi I) dan aseton (variasi II). Tujuan ditambahkan air dan aseton ini adalah untuk meningkatkan derajat substitusi. Pada derajat substitusi (DS) yang berbeda, kelarutan metil selulosa pun akan berbeda. Metil selulosa yang meiliki nilai DS 1,3-2,5 akan larut dalam air dingin, nilai DS > 2,5 larut dalam asam asetat glasial, nilai DS 0,4-0,6 larut dalam $\mathrm{NaOH}$. Sampel dengan perlakuan aseton memiliki tingkat substitusi yang lebih tinggi, yang berhubungan dengan cara efektif pelarut aseton berinteraksi dengan gugus hidroksil, yaitu dengan mengurangi jumlah ikatan hidrogen rantai luar (Viera, 2007).

Reaksi eterifikasi yang menggunakan metilen klorida bekerja pada suhu $60-70^{\circ} \mathrm{C}$. Oleh karena itu, dalam tahap ini campuran direfluks agar komponen dalam campuran tetap (tidak ada yang berubah) dan reaksi bekerja optimal. Kemudian, pemurnian dan penghilangan produk samping dilakukan dengan mencuci menggunakan air panas, dilanjutkan dengan pengeringan dan penghalusan metil selulosa yang telah dihasilkan. Metil selulosa larut dalam air dingin (suhu sekitar $5^{\circ} \mathrm{C}$ ). Oleh sebab itu, pada saat proses pencucian menggunakan air panas agar metil selulosa tidak ikut larut dengan pengotor.
Metil selulosa yang telah dicuci dengan air panas kemudian dikalsinasi pada suhu $50^{\circ} \mathrm{C}$ selama 6 jam. Suhu tersebut dipilih karena pada suhu terlalu tinggi metil selulosa yang dihasilkan akan rusak. Metil selulosa yang dihasilkan berupa padatan berwarna putih untuk metil selulosa-air (variasi I) dan padatan berwarna kekuningan untuk metil selulosa-aseton (variasi II). Metil selulosa-air dan metil selulsoa-aseton dapat dilihat pada Gambar 4.

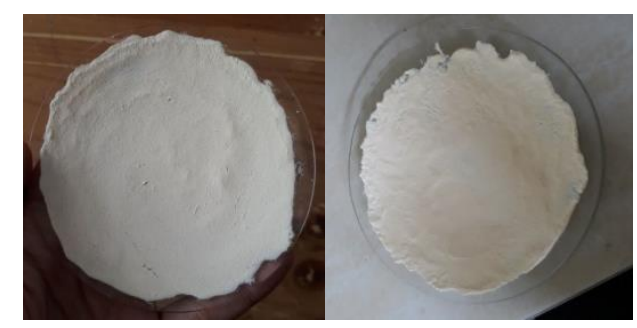

Gambar 4. Metil selulosa-air dan -aseton

\section{Analisis FTIR selulosa dan metil selulosa}

Analisis menggunakan FTIR dilakukan untuk mengidentifikasi gugus metil pada selulosa dari hasil metilasi, serta adanya senyawa lain yang masih terdapat dalam sampel. Berdasarkan Tabel 1 spektrum selulosa muncul pada bilangan gelombang 3443,29 $\mathrm{cm}^{-1}$ yang menunjukkan ikatan, 2920,23 $\mathrm{cm}^{-1}$ untuk menunjukkan ikatan $\mathrm{C}-\mathrm{H}$ (posisi C6), dan 1340,53 $\mathrm{cm}^{-1}$ untuk menunjukkan ikatan $\mathrm{C}-\mathrm{H}$ (posisi $\mathrm{C} 2$ atau $\mathrm{C} 3$ ). Berdasarkan penelitian sebelumnya, keberadaan spektrum pada bilangan gelombang sekitar 1630$1750 \mathrm{~cm}^{-1}$ menunjukkan ikatan $\mathrm{C}=\mathrm{C}$ pada cincin yang berasal dari lignin (Kondo, 1994). Untuk lebih jelasnya hasil FTIR selulosa dapat dilihat pada Gambar 5.

Tabel 1. Gugus fungsi selulosa - metil selulosa

\begin{tabular}{llll}
\hline $\begin{array}{l}\text { Gugus } \\
\text { fungsi }\end{array}$ & Selulosa & $\begin{array}{l}\text { Metil } \\
\text { selulsa-air }\end{array}$ & $\begin{array}{l}\text { Metil sel- } \\
\text { aseton }\end{array}$ \\
\hline -OH & 3433,29 & 3444,87 & 3442,94 \\
regangan & 3288,63 & - & - \\
& 3178,69 & - & - \\
C-H & 2920,23 & 2899,01 & 2900,94 \\
$\beta$-glikos & 896,90 & 896,90 & 896,90 \\
C=C (lignin) & 1641,42 & 1639,49 & - \\
H-C-H & 1340,53 & 1413,82 & 1409,96 \\
\hline
\end{tabular}




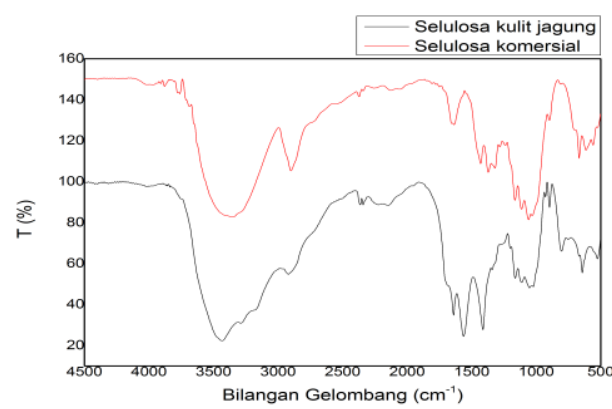

Gambar 5. Hasil FTIR selulosa komersial dan selulosa kulit jagung

Pada Gambar 5 terlihat dua spektrum, yang berwarna hitam merupakan spektrum selulosa hasil sintesis dan spektrum yang berwarna merah merupakan spektrum selulosa komersial. Terdapat sedikit perbedaan antara selulosa hasil sintesis dengan selulosa komersial. Lignin pada selulosa komersial berkurang sedangkan pada selulosa hasil sintesis lignin masih terlihat. Lignin tersebut ditunjukkan pada bilangan gelombang sekitar $1630-1750 \mathrm{~cm}^{-1}$. Perbedaan lain juga terlihat pada puncak O-H sekitar bilangan gelombang $3400 \mathrm{~cm}^{-1}$. Pada selulosa komersial hanya terdapat satu puncak $\mathrm{O}-\mathrm{H}$ sedangkan pada selulosa hasil sintesis terdapat tiga puncak O-H. O-H dari hasil sintesis kemungkinan diperoleh dari $\mathrm{NaOH}$ atau $\mathrm{H}_{2} \mathrm{O}$ yang masih tertinggal pada saat sintesis.

Jika dibandingkan hasil FTIR dari spektrum selulosa dan metil selulosa (Tabel 1) terlihat bahwa gugus $\mathrm{O}-\mathrm{H}$ pada seulosa digantikan dengan gugus metil pada metil selulosa sehingga gugus $\mathrm{O}-\mathrm{H}$ pada metil selulosa intensitasnya menurun sedangkan intensitas puncak serapan gugus $\mathrm{C}-\mathrm{H}$ meningkat. Seperti yang terlihat pada $\mathrm{C}-\mathrm{H}$ (posisi $\mathrm{C} 2$ atau $\mathrm{C} 3$ ) yang mengalami peningkatan dari $1340,53 \mathrm{~cm}^{-1}$ pada selulosa menjadi $1413,82 \mathrm{~cm}^{-1}$ pada metil selulosa-air dan $1409,96 \mathrm{~cm}^{-1}$ metil selulosa-aseton. Ini membuktikan bahwa pada proses metilasi selulosa berhasil, selulosa telah berubah menjadi metil selulosa. Untuk lebih jelasnya perubahan tersebut dapat dilihat pada hasil FTIR Gambar 6. Dari data absorbansi FTIR ini juga dilakukan perhitungan rasio $\mathrm{OH} / \mathrm{CH}$ untuk mengetahui seberapa banyak $\mathrm{OH}$ yang tersubstitusi oleh $\mathrm{CH}$. Semakin kecil rasio $\mathrm{OH} / \mathrm{CH}$, maka semakin banyak $\mathrm{OH}$ yang tersubstitusi oleh $\mathrm{CH}$. Dari hasil perhitungan diketahui bahwa rasio $\mathrm{OH} / \mathrm{CH}$ dari metil selulosa-air dan metil selulosa aseton sebesar 1,9019 dan 1,9835. Nilai keduanya tidak jauh berbeda hanya selisih 0,0816. Hal ini menunjukan bahwa banyaknya $\mathrm{OH}$ yang tersubstitusi oleh $\mathrm{CH}$ pada metil selulosa-air dan metil selulosa-aseton jumlahnya hampir sama (Rokhade, 2007).

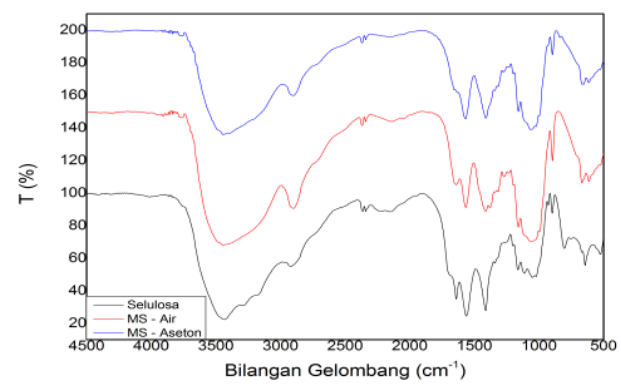

Gambar 6. Hasil FTIR selulosa, metil selulosaair, metil selulosa-aseton

\section{Uji kelarutan dan uji titik leleh metil selulosa}

Uji kelarutan dilakukan dengan melarutkan metil selulosa dalam beberapa larutan, seperti larutan $\mathrm{NaOH} 4 \%$, larutan $\mathrm{CH}_{3} \mathrm{COOH}$ glasial, dan aquades $\left(\mathrm{T}=(5-15)^{\circ} \mathrm{C}\right)$. Ketiga larutan tersebut memiliki nilai DS (derajat substitusi) yang berbeda. Derajat substitusi didefinisikan sebagai jumlah rata-rata substituen per unit anhidro glukosa. Nilai DS ini menunjukan seberapa banyak gugus $\mathrm{O}-\mathrm{H}$ pada selulosa yang tersubstitusi oleh $\mathrm{CH}_{3}$ pada saat proses metilasi.

Dari uji kelarutan tersebut diketahui bahwa metil selulosa-air larut dalam larutan $\mathrm{NaOH} 4 \%$, namun tidak larut dalam larutan $\mathrm{CH}_{3} \mathrm{COOH}$ glasial, dan aquades $\left(\mathrm{T}=(5-15)^{\circ} \mathrm{C}\right)$. Hal yang sama juga terjadi pada metil selulosa-aseton. Kedua hal tersebut menunjukkan bahwa metil selulosa-air dan metil selulosa-aseton memiliki nilai DS sekitar 0,4-0,6.

Selain uji kelarutan, dilakukan pula uji titik leleh. Setelah dilakukan pengujian pada metil selulosa-air dan metil selulosa-aseton, keduanya tidak mempunyai titik leleh karena pada suhu $240^{\circ} \mathrm{C}$ kedua metil selulosa tersebut belum meleleh tetapi malah terbakar. Hal ini menunjukan bahwa metil selulosa yang dihasilkan belum termetilasi sempurna. Karena metil selulosa yang termetilasi sempurna mempunyai titik leleh sekitar suhu (290-305) ${ }^{\circ} \mathrm{C}$. 


\section{KESIMPULAN}

Dari hasil penelitian ini dapat diambil beberapa kesimpulan sebagai berikut: Selulosa dari kulit jagung berhasil diisolasi dengan munculnya puncak pada bilangan gelombang $3433,29 \mathrm{~cm}^{-1}$ untuk O-H, $2920,23 \mathrm{~cm}^{-1}$ untuk C$\mathrm{H}, 896,90 \mathrm{~cm}^{-1}$ untuk ikatan $\beta$-glikosidik. Selulosa hasil isolasi ini memiliki karakteristik berupa padatan berwarna putih, tidak larut dalam air, sebagian larut dalam $\mathrm{NaOH}$.

Metil selulosa-air dan metil selulosa-aseton berhasil disintesis dengan munculnya puncak pada bilangan gelombang $3444,87 \mathrm{~cm}^{-1}$ untuk O$\mathrm{H}$ (metil selulosa-air) dan $3442,94 \mathrm{~cm}^{-1}$ untuk O$\mathrm{H}$ (metil selulosa-aseton), 2899, $01 \mathrm{~cm}^{-1}$ untuk C$\mathrm{H}$ (metil selulosa-air) dan 2900,94 $\mathrm{cm}^{-1}$ untuk C$\mathrm{H}$ (metil selulosa-aseton). Metil selulosa yang dihasilkan memiliki karakteristik berupa padatan berwarna putih (metil selulosa-air) atau sedikit kuning (metil selulosa-aseton), larut dalam $\mathrm{NaOH} 4 \%$ tetapi tidak larut dalam $\mathrm{CH}_{3} \mathrm{COOH}$ glasial dan akuades suhu $(5-15)^{\circ} \mathrm{C}$.

Hasil dari variasi penambahan air dan aseton tidak meningkatkan nilai derajat substitusi yang signifikan. Nilai derajat substitusi dari metil selulosa-air dan metil selulosa-aseton sekitar 0,4 $-0,6$.

\section{DAFTAR PUSTAKA}

Dirgantara, M., Saputra, M., Khalid, M., Wahyuni, E. S., \& Kurniati, M. (2013). Karakterisasi mekanik biokomposit klobot jagung sebagai bahan dasar plastik biodegradable. Program Kreativitas Mahasiswa-Penelitian. Dirjen Dikti, Jakarta.

Ginting, A. (2016). Pemanfaatan Limbah Kulit Jagung untuk Produk Modular dengan Teknik Pilin. Dinamika Kerajinan dan Batik: Majalah Ilmiah, 32(1), 51-62.

Kondo, T., Sawatari, C., Manley, R. S. J., \& Gray, D. G. (1994). Characterization of hydrogen bonding in cellulose-synthetic polymer blend systems with region selectively substituted methyl cellulose. Macromolecules, 27(1), 210215.

Nasatto, P. L., Pignon, F., Silveira, J. L., Duarte, M. E. R., Noseda, M. D., \& Rinaudo, M. (2015). Methylcellulose, a cellulose derivative with original physical properties and extended applications. Polymers, 7(5), 777-803.

Pinotti, A., García, M. A., Martino, M. N., \& Zaritzky, N. E. (2007). Study on microstructure and physical properties of composite films based on chitosan and methylcellulose. Food Hydrocolloids, 21 (1), 66-72.

Rachmawati, L., Rusmiyati, S. (2013). Bolero Kulit Jagung Dengan Inspiration Picture Rumah Gadang. Jurnal Tata Busana, 2(3), 52-60.

Rimdusit, S., Jingjid, S., Damrongsakkul, S., Tiptipakorn, S., \& Takeichi, T. (2008). Biodegradability and property characterizations of methyl cellulose: effect of nanocompositing and chemical crosslinking. Carbohydrate polymers, 72(3), 444-455.

Rokhade, A. P., Shelke, N. B., Patil, S. A., \& Aminabhavi, T. M. (2007). Novel interpenetrating polymer network microspheres of chitosan and methyl cellulose for controlled release of theophylline. Carbohydrate Polymers, 69 (4), 678-687.

Sumarwan, U. (2016). Perubahan Pola Konsumsi Pangan Beras, Jagung dan Terigu Konsumen Indonesia Periode 1999-2009 dan Implikasinya Bagi Pengembangan Bahan Bakar Ramah Lingkungan Berbasis Pangan. Jurnal Pangan, 19(2), 157-168.

Viera, R. G., Rodrigues Filho, G., de Assunção, R. M., Meireles, C. D. S., Vieira, J. G., \& de Oliveira, G. S. (2007). Synthesis and characterization of methylcellulose from sugarcane bagasse cellulose. Carbohydrate Polymers, 67(2), 182-189. 